Bechelli, L. M., et al. (1970). Bulletin of the World Health Organization, 42,235 .

British Tuberculosis Association (1966). Tubercle, 47, 145.

Brown, J. A. K., Stone, M. M., and Sutherland, I. (1966). British Medical fournal, 1,7.

Brown, J. A. K., Stone, M. M., and Sutherland, I. (1968). British Medical fournal, 1, 24.
Hart, P. D'A., Sutherland, I., and Thomas, J. (1967). Tubercle, 48, 201

Medical Research Council (1956). British Medical fournal, 1, 413.

Medical Research Council (1959). British Medical fournal, 2, 379.

Medical Research Council (1963). British Medical fournal, 1, 973.

Springett, V. H. (1969). Tubercle, 50, 159.

Tolderlund, K. (1952). Acta Pathologica et Microbiologica Scandinaeica, Suppl., 93, 299.

\title{
Effect of Temperature on Hospital Admissions for Myocardial Infarction in a Subarctic Area
}

\author{
E. SOTANIEMI,* M.D. ; U. VUOPALA, $†$ M.D. ; E. HUHTI, † M.D. ; J. TAKKUNEN, $\ddagger$ M.D.
}

British Medical Fournal, 1970, 4, 150-151

\begin{abstract}
Ummary: In a study of the effect of mean daily tempera$\checkmark$ ture on the admission and fatality rates of 771 patients with myocardial infarction the admission rate was found to be significantly higher on cold (temperature below $0^{\circ} \mathrm{C}$.) than on warm (temperature above $0^{\circ} \mathrm{C}$.) days. The fatality rate was almost equal in cold and warm weather. Thus the seasonal fluctuation in the admission rate of patients with myocardial infarction is probably due to a direct effect of environmental temperature.
\end{abstract}

\section{Introduction}

A seasonal fluctuation has been noted in numerous studies concerning the incidence of myocardial infarction. In the temperate and cold zones it has generally been found to be higher in winter than in summer (Bean and Mills, 1938; Ekvall, 1955; Dotzauer and Naeve, 1956; Gorbatow, 1961; Vartio et al., 1964; Rose, 1966), but there are exceptions (Mintz and Katz, 1947; Master and Jaffe, 1952; Westlund, 1965). On the other hand, in subtropical regions there is a definite increase in the hospital admission rate of myocardial infarction during the hot summer months compared with the cooler winter months (Heyer et al., 1953; DePasquale and Burch, 1961). Thus the relation between environmental temperature and myocardial infarction is still uncertain.

Other problems that remain unsolved are whether the fatality rate of myocardial infarction increases with a deviation from the optimum temperature (Lancet, 1970), and whether temperature variations may have different effects in different countries, as some of the results seem to suggest (Anderson and Le Riche, 1970). The incidence of respiratory infections increased during the cold season (Holland et al., 1961), and Anderson and Le Riche (1970) thought that the seasonal fluctuation in the mortality from ischaemic heart disease was mainly due to the seasonal fluctuation in respiratory disease. If this is the case one would expect the fatality rate to be higher among patients with myocardial infarction entering hospital during the cooler periods of the year, when the respiratory infections are more prevalent.

We present the results of an investigation into the relation between myocardial infarction and the environmental temperature. The patients came from a limited area in the North of Finland, where a subarctic climate prevails and the differences between seasonal temperatures are pronounced.

\footnotetext{
* Senior Lecturer in Medicine.

Physician.

Associate Professor in Medicine.

Department of Medicine, University of Oulu, Oulu, Finland.
}

\section{Patients and Methods}

$\mathrm{Al}$ ! patients with myocardial infarction treated at the deparment of medicine, University of Oulu, from 1965 to 1968 are included-a total of 771 cases. The population of the area served by the hospital is about 300,000 , but some patients are admitted into the smaller hospitals, and, because of the long distances, do not reach the hospital until after the onset of intarction. Most of the patients come from the city of Oulu (population 90,000) and the surrounding rural districts. Diagnisis was based on the usual anamnestic, clinical, laboratory, and electrocardiographic criteria.

Oulu is situated on the Gulf of Bothnia in Northern Finland, almos: exactly at latitude $65^{\circ} \mathrm{N}$. Its mean annual temperature during the period of investigation was $+1.2^{\circ} \mathrm{C}$. (the mean temperature for the coldest month being $-15.9^{\circ} \mathrm{C}$. and $\mathrm{Co}^{\circ}$ the warmest month $+15.4^{\circ} \mathrm{C}$.) and the mean annual rair all $512 \mathrm{~mm}$.

The investigatun covered 1,461 days. The daily mean temperatures were recurded by the meteorological station at Oulu airport. The days were divided into seven groups according to their mean temperatures: the coldest group included the days with a mean temperature below $-30^{\circ} \mathrm{C}$. and the warmest those with a mean temperature above $+20^{\circ} \mathrm{C}$. The other groups lay between these extremes. The number of patients with myocardial infarction admitted to hospital each day was then ascertained, and distributed into the above-mentioned day groups. The fatality rate in each group during the hospital stay was also calculated; the length of stay-three or four weeks, according to the severity of infarction (Takkunen et al., 1969)-was equal in all groups. As no difference was found in the distribution of patients with first and subsequent infarctions, these two groups were combined.

\section{Results}

The distribution of patients into groups based on the daily mean temperatures is shown in the Table. On 867 days (59\%)

Effect of Mean Daily Temperature on Admissions for and Prognosis of Myocardial Infarction

\begin{tabular}{|c|c|c|c|c|c|c|c|c|c|}
\hline \multirow{2}{*}{$\begin{array}{c}\text { Daily } \\
\text { Temperature } \\
\left({ }^{\circ} \mathrm{C} .\right)\end{array}$} & \multicolumn{2}{|c|}{ Days } & \multicolumn{3}{|c|}{$\begin{array}{l}\text { Myocardial } \\
\text { Infarctions }\end{array}$} & \multicolumn{3}{|c|}{ Deaths } & \multirow{2}{*}{$\begin{array}{c}\text { Fatality } \\
\text { Rate } \\
(\%)\end{array}$} \\
\hline & No. & ") & No. & "o & $\begin{array}{l}\text { Per } \\
\text { Day }\end{array}$ & No. & \% & $\begin{array}{l}\text { Per } \\
\text { Day }\end{array}$ & \\
\hline $\begin{array}{r}--30 \\
-30-20 \\
-19-10 \\
+9-+0 \\
+10-+19 \\
+20-+30\end{array}$ & $\begin{array}{r}7 \\
79 \\
163 \\
345 \\
458 \\
394 \\
15\end{array}$ & $\begin{array}{r}0.5 \\
5.4 \\
11.0 \\
23.7 \\
31.4 \\
27.0 \\
1.0\end{array}$ & $\begin{array}{r}5 \\
53 \\
125 \\
202 \\
200 \\
178 \\
8\end{array}$ & $\begin{array}{r}0.6 \\
6 \cdot 9 \\
16 \cdot 3 \\
26 \cdot 1 \\
26 \cdot 0 \\
23 \cdot 1 \\
1.0\end{array}$ & $\begin{array}{l}0.71 \\
0.67 \\
0.76 \\
0.59 \\
0.44 \\
0.45 \\
0.55\end{array}$ & $\begin{array}{r}0 \\
15 \\
37 \\
58 \\
49 \\
45 \\
1\end{array}$ & $\begin{array}{r}0 \\
7.3 \\
18.0 \\
28.3 \\
24.0 \\
21.9 \\
0.5\end{array}$ & $\begin{array}{l}0 \\
0 \cdot 19 \\
0 \cdot 23 \\
0 \cdot 17 \\
0 \cdot 10 \\
0 \cdot 11 \\
0.07\end{array}$ & $\begin{array}{c}0 \\
28 \cdot 3 \\
29 \cdot 6 \\
28 \cdot 7 \\
24 \cdot 5 \\
25 \cdot 3 \\
12 \cdot 5\end{array}$ \\
\hline
\end{tabular}


the mean temperature was above $0^{\circ} \mathrm{C}$. and on 594 days ( $41 \%$ ) it was below $0^{\circ} \mathrm{C}$. The corresponding hospital admissions amounted to $386(50 \%)$ and $385(50 \%)$. On days with a mean temperature above $0^{\circ} \mathrm{C}$. 0.445 patient per day was admitted, the respective figure for days with a mean temperature below $0^{\circ} \mathrm{C}$. being 0.648 . The difference is significant $\left(\mathrm{P}<0.001\right.$ by the $\chi^{2}$ tesi $)$. The admission rate was lowest when the daily mean temperature ranged from 0 to $+9^{\circ} \mathrm{C}$., and highest on days with a mean temperature from -19 to $-10^{\circ} \mathrm{C}$.

Of the 205 patients $(26 \%)$ who died while in hospital, 110 $(29 \%)$ were admitted on cold days (mean temperature below $0^{\circ} \mathrm{C}$.) and $95(25 \%)$ on warmer days; the difference is not significant. The fatality rate in each temperature group appears to be about the same (see Table). Of the $194(25 \%)$ patients who had their attack of infarction while outdoors, 88 $(23 \%)$ entered hospital on cold days and $106(27 \%)$ entered on warm days.

\section{Discussion}

Our results indicate that admissions for myocardial infarction increased on days with a low mean temperature. The most favourable temperature in our area was 0 to $+9^{\circ} \mathrm{C}$. When the mean temperature was below $0^{\circ} \mathrm{C}$. substantially more patients were admitted daily than when it was higher. The daily number of admissions increased with the fall of temperature to $-20^{\circ} \mathrm{C}$; ; it then remained constant. Our results agree with earlier observations which show a winter peak in admissions for myocardial infarction (Bean and Mills, 1938; Ekvall, 1955; Dotzauer and Naeve, 1956; Gorbatow, 1961; Rose, 1966; Anderson and Le Riche, 1970). In most of the studies which attempt to explain the seasonal variations in the incidence of and mortality from myocardial infarction only monthly and seasonal mean temperatures have been considered. In Oulu considerable variations may occur in daily means within one month. An acute change in environmental temperature tends to increase myocardial oxygen consumption (Ansari and Bruch, 1969; Epstein et al., 1969) and may thus induce cardiac arrhythmias or an anginal attack. It seemed appropriate, therefore, to examine daily temperatures and their bearing on the admission rate. The effects of high temperature cannot be adequately examined in Oulu, since daily mean temperatures exceeded $+20^{\circ} \mathrm{C}$. only 15 times during the period of investigation.

For comparison the patients were divided into groups according to the mean temperature of the month of their admission. The investigation period included 28 months with a mean temperature above $0^{\circ} \mathrm{C}$. and 20 months with a mean temperature below $0^{\circ} \mathrm{C}$. During the warm months 444 patients were admitted (15.9 patients per month) and during the cold months 327 (16.4 patients per month). This difference is not significant.
Possibly the journey to hospital takes longer during the cold season because of various delays-for example, bad roads-and consequently more patients die before arrival. It has been our policy in recent years, however, to take forceful resuscitative measures in all cases where myocardial infarction has a possibility, even when the patient was obviously dead when arriving at the hospital. Regardless of the success of resuscitation all these patients were included if the myocardial infarction could be confirmed later. During the period covered by the investigation 50 patients were brought to hospital who were not resuscitated, yet were thought to have died of myocardial infarction-28 were brought on cold days (mean temperature below $0^{\circ} \mathrm{C}$.) and 22 on warm days (mean temperature above $0^{\circ} \mathrm{C}$.). (These patients are not included in the 771 cases.) Even if these are taken into account there is no significant difference in the fatality rate, whether the patients were admitted on cold or warm days. Thus the environmental temperature probably has little, if any, bearing on the severity of infarction. The obvious effect of cold weather on the admission rate of myocardial infarction might, of course, be due to the rising frequency of some concurrent disease-for example, respiratory infection. The fact that the fatality rate does not change significantly with the temperature suggests that this is not the case, an assumption supported by Rose's (1966) results. No difference could be shown in patients' outdoor activities, whether the infarction occurred in cold or warm weather.

\section{REFERENCES}

Anderson, T. W., and Le Riche, W. H. (1970). Lancet, 1, 291.

Ansari, A., and Burch, G. E. (1969). Archives of Internal Medicine, 123, 371. Bean, W. B., and Mills, C. A. (1938). American Heart fournal, 16, 701.

DePasquale, N. P., and Burch, G. E. (1961). American fournal of the Medical Sciences, 242, 468

Dotzauer, G., and Naeve, W. (1956). Deutsche Zeitschrift für die gesamte gerichtliche Medizin, 45, 30 .

Ekvall, S. (1955). Cardiac Infarcts, Umea Ventenskapliga bibliotek Skrifter.

Epstein, S. E., Stampfer, M., Beiser, D., Goldstein, R. E., and Braunwald, E. (1969). New England fournal of Medicine, 280, 7.

Gorbatow, O. (1961). Acta Medica Scandinavica, 169, Suppl. No. 364.

Heyer, H. E., Teng, H. C., and Barris, W. (1953). American Heart Fournal, 45,741 .

Holland, W. W., Spicer, C. C., and Wilson, J. M. G. (1961). Lancet, 2, 338.

Lancet, 1970, 1, 282.

Master, A. M., and Jaffe, H. L. (1952). Fournal of the American Medical Association, 148, 794.

Mintz, S. S., and Katz, L. N. (1947). Archives of Internal Medicine, 80, 205.

Rose, G. (1966). British fournal of Preventive and Social Medicine, 20, 97.

Takkunen, J., Huhti, E., Tuomaala, R., Waris, E., and Kaipainen, W. J. (1969). Annals of Clinical Research, 1, 246.

Vartio, T., Meronen, R., and Sotaniemi, E. (1964). Sotilaslaäketieteellinen Aikakauslehti, 5, 3.

Westlund, K. (1965). Fournal of the Oslo City Hospitals, 15, 201. 